\title{
Pengembangan Lembar Kerja Siswa dengan Model Pembelajaran Koperatif Tipe Kreatif-Produktif untuk Memfasilitasi Kemampuan Pemahaman Konsep Matematis Siswa SMP Negeri 21 Pekanbaru
}

\author{
Nazilatul Wahidah, Hasanuddin, Hartono \\ Prodi Pendidikan Matematika, Universitas Islam Negeri Sultan Syarif Kasim Riau \\ Jl. H.R. Soebrantas KM 15.5, Tampan, Pekanbaru, Indonesia, 28293 \\ Email: nazilatul.wahidah@student.uin-suska.ac.id, hasanuddin@uin-suska.ac.id
}

\begin{abstract}
Abstrak. Penelitian ini didasarkan pada permasalahan rendahnya pemahaman konsep matematis siswa dan minimnya penggunaan lembar kerja siswa saat proses pembelajaran. Sebagai alternatif dari permasalahan tersebut dilakukan penelitian dengan mengembangkan Lembar Kerja Siswa dengan model pembelajaran kooperatif tipe kreatif-Produktif dalam pembalajaran Penelitian ini bertujuan untuk mendeskripsikan LKS matematika model Kreatif-Produktif yang valid dan praktis dalam memfasilitasi kemampuan pemahman konsep matematis siswa. Jenis penelitian ini merupakan penelitian pengembangan dengan menggunakan model ADDIE (Analysis, Design, Development, Implementation, dan Evaluation). Penelitian ini dilakukan di Sekolah Menengah Pertama Negeri 21 Pekanbaru. Subjek penelitian adalah 40 siswa kelas VIII.1 dan objek penelitian adalah LKS matematika berbasis Problem Based Instruction. Jenis data yang diambil dalam penelitian ini adalah data kualitatif dan kuantitatif. Teknik pengumpulan data berupa angket uji validitas, angket uji praktikalitas, dan tes. Data yang diperoleh kemudian dianalisis dengan teknik analisis deskriptif. LKS hasil pengembangan telah teruji dengan tingkat kevalidan 82,8\% (sangat valid) dan tingkat kepraktisan 89,7\% (sangat praktis). LKS model Kreatif-Produktif telah berhasil dalam memfasilitasi kemampuan pemahaman konsep matematis siswa, hal ini ditunjukkan dengan nilai rata-rata tes kemampuan pemahaman konsep matematis siswa berada pada kriteria tinggi dengan persentase $92 \%$. Berdasarkan hasil tersebut mengidentifikasikan bahwa LKS model kreatifproduktif yang dikembangkan valid dan praktis dalam memfasilitasi kemampuan pemahaman konsep matematis siswa.
\end{abstract}

Kata Kunci: LKS, Kreatif-Produktif, Pemahaman Konsep.

\section{PENDAHULUAN}

Matematika merupakan salah satu cabang ilmu pengetahuan dalam dunia pendidikan.Matematika sebagai ilmu juga berfungsi untuk melayani ilmu pengetahuan. Tujuan Pembelajaran matematika yang dirusmuskan dalam Peraturan Menteri Pendidikan Nasional RI Nomor 20 tahun 2006 tentang standar isi, menyatakan bahwa mata pelajaran matematika salah satunya bertujuan agar peserta didik memiliki kemampuan pemahaman konsep matematis, menjelaskan keterkaitan antar konsep dan mengaplikasikan konsep atau algoritma secara luawes, akurat, efisien dan tepat dalam pemecahan masalah (Menteri Pendidikan Nasional, 2006). Kemampuan pemahaman konsep matematis merupakan kemampuan yang diperlukan dalam belajar matematika. Selain itu, diperlukan juga dalam menghadapi masalah dalam kehidupan siswa, karena kemampuan pemahamanan konsep matematika adalah kemampuan yang paling dasar dalam mempelajari matematika. Suherman (2001, p.61) mengemukakan bahwa penekanan dalam pembelajaran matematika tidak hanya melatih keterampilan dan menghafal fakta, tetapi melatih pada pemahaman konsep. Pernyataan tersebut menjelaskan bahwa pembelajaran matematika bukan sekedar memberi pengetahuan saja, tetapi lebih diperhatikan dalam memahami konsep pada setiap materi yang dipelajari. Pemahaman konsep matematis yang baik akan menjadi pengantar kepada kemampuan-kemapuan berfikir tingkat tinggi lainnya. 
Beberapa riset menemukan bahwa masih rendahnya kemampuan pemahan konsep siswa (Utari, Fauzan, \& Rosha, 2012). Indikasi tersebut dapat dilihat melalui hasil tes pemahaman konsep siswa masih tergolong rendah (Rusia, Fahinu, \& Tiya, 2016). Jawaban siswa terlihat bahwa siswa kurang hati-hati dalam menyelesaikan soal (Hutagalung, 2017). Siswa kurang memahami apa yang dimaksud soal sehingga nilai siswa untuk kemampuan pemahaman konsep ikut menjadi rendah (sumarsih, 2016; Tuzahrah, Rasiman, \& Ijuddin, 2016).

Gejala-gejala kemampuan pemahaman konsep matematis yang rendah tersebut, harus diberi solusi dengan cara guru lebih meningkatkan mutu pembelajaran. Guru dapat memberikan bahan ajar yang tepat agar kemamampuan pemahaman konsep matematis siswa dapat tercapai sesuai dengan tujuan pembelajaran. Bahan ajar yang dapat menunjang tujuan pendidikan yaitu Lembar Kerja Siswa. Penggunaaan LKS diharapkan dapat meminimalkan peran pendidik, mengaktifkan peserta didik serta mempermudah peserta didik untuk memahami materi yang diberikan, melatih siswa dalam mengerjakan soal dan menghemat waktu dalam proses pembelajaran. Sehingga LKS yang telah ada dengan model pembelajaran dapat mendukung siswa dalam pemahaman materi diharapkan dan dapat menjawab soal -soal yang tertera pada latihan serta membuat siswa menjadi lebih aktif, kreatif dan produktif dalam mengembangkan sendiri pengetahuannya. Berdasarkan hasil penelitian yang telah dilakukan oleh Saltifa, dkk (2012) bahwa penggunaan lembar kerja siswa (LKS) dapat meningkatkan kemampuan pemahaman konsep matematis siswa.

Salah satu model pembelajaran yang bisa digunakan dalam pembelajaran adalah model kreatif-produktif. Model pembelajaran kreatif-produktif merupakan model pembelajaran dengan penyajian materi ajar yang mendorong siswa untuk mengembangkan ide kreatif yang produktif (Istarani \& Ridwan, 2014). Strategi pembelajaran kreatif-produktif memiliki beberapa karakteristik yang membedakannya dengan strategi lainnya, salah satunya yaitu siswa didorong untuk menemukan/mengkontruksikan sendiri konsep yang sedang dikaji melalui penafsiran yang dilakukan dengan berbagai cara seperti observasi, diskusi atau percobaan (Wena, 2011, p. 140). Berdasarkan karakteristik tersebut, maka model pembelajaran kreatif-produktif dapat digunakan untuk meningkatkan pemahaman konsep siswa, karena siswa didorong untuk menemukan/mengkontruksikan sendiri konsep yang sedang dikaji melalui penafsiran yang dilakukan dengan berbagai cara seperti observasi.

Berdasarkan uraian disampaikan, penelitian ini bertujuan untuk menghasilkan LKS matematika model Kreatif-Produktif yang valid dan praktis dalam memfasilitasi kemampuan pemahaman konsep matematis siswa SMP/MTS kelas VIII semester 2.

\section{TINJAUAN LITERATUR}

\section{Pemahaman Konsep Matematika}

Pemahaman (comprehension) menurut Zein dan Darto (2012, p. 17) adalah kemampuan menangkap arti materi pelajaran berupa kata, angka dan menjelaskan sebab akibat. Sedangkan, konsep merupakan sesuatu yang mucul karna adanya kemampuan manusia dalam membedakan, mengelompokkan dan menamakan suatu istilah (Uno, 2011, p. 10). Penamaan ini mengacu kepada objek tertentu, seperi objek matematika. Selanjutnya, objek matematika tersebut dapat berupa fakta, konsep, operasi dan pinsip yang semuanya berperan dalam membentuk poses berfikir matematis (Risnawati, 2008).

Konstruksi antara pemahaman dan kosep melahirkan istilah pemahaman konsep. Jadi, Pemahaman konsep dapat didefinisikan sebagai kemampuan mengetahui serta menginternalisasi suatu materi pembelajaran melalui kemapuan membedakan, mengelompokkan dan menamakan sesuatu. Kemampuan tersebut didasarkan pada apa yang telah dipelajari dan alasan mempelajarnya. 
Pengaitan pemahama konsep terhadap objek matematika melahirkan istilah kemampuan pemahaman konsep matematis.

Menurut Badan Standar Nasional Pendidikan (2006) indikator-indikator yang menunjukkan pemahaman konsep yaitu 1) Menyatakan ulang sebuah konsep, yaitu kemampuan siswa untuk mengungkapkan kembali apa yang telah dikomunikasikan kepadanya bak lisan maupun tulisan. 2) Mengklasifikasikan objek menurut sifat-sifat tertentu sesuai dengan konsepnya, yaitu kemampuan siswa untuk dapat mengelompokkan objek menurut sifat-sifat. 3) Memberi contoh dan non contoh dari konsep, yaitu kemampuan siswa dapat membedakan contoh dan bukan contoh dari suatu matari yang telah dipelajari. 4) Menyajikan konsep dalam berbagai bentuk representasi matematis yaitu kemampuan siswa menggambar atau membuat grafik, membuat ekspesi matematiks, menyusun cerita atau teks tertulis. 5) Mengembangkan syarat perlu atau syarat cukup dari suatu konsep, yaitu kemampuan siswa mengkaji mana syarat perlu atau cukup suatu konsep yang terkait. 6) Menggunakan, memanfaatkan, dan memilih prosedur tertentu, yaitu kemampuan siswa menyelesaikan soal dengan tepat sesuai dengan prosedur. Dan, 7)Mengaplikasikan konsep atau algoritma pemecahan masalah, yaitu kemampuan siswa menggunakan konsep atau prosedur dalam menyelesaikan masalah yang berkaitan dengan kehidupan sehari-hari.

W.Gulo (2008) menyatakan bahwa kemampuan-kemampuan yang tergolong dalam pemahaman, mulai dari yang terendah sampai yang tertinggi adalah sebagai berikut: 1) Translasi, yaitu kemampuan mengubah simbol tertentu menjadi simbol lain tanpa perubahan makna. Simbol berupa kata-kata (verbal) diubah menjadi gambar atau bagan ataupun grafik. 2) Interprtasi, yaitu kemampuan untuk menjelaskan makna yang terdapat di dalam simbol, baik simbol verbal maupun yang nonverbal. Dalam kemampuan ini, seseorang dapat menginterpretasikan suatu konsep atau prinsip jika ia dapat menjelaskan secara rinci makna atau konsep atau prinsip, atau dapat membandingkan, membedakan, atau mempertentangkan dengan sesuatu yang lain. Dan 3) Ekstrapolasi, yaitu kemampuan untuk melihat kecendrungan atau arah atau kelanjutan dari suatu temuan.

\section{Lembar Kerja Siswa (LKS)}

Lembar Kerja Siswa (LKS) adalah materi bahan ajar yang sudah dikemas sedemikian rupa, sehingga peserta didik dapat mempelajari materi ajar secara mandiri (Prastowo, 2013, p.204). LKS peserta didik tidak hanya berisi lembaran tugas tetapi terdapat serangkaian materi ringkasan untuk memahami soal yang diberikan. Lembar kerja siswa memuat sekumpulan kegiatan-kegiatan dasar yang harus dilakukan oleh siswa untuk memaksimalkan pemahaman dalam upaya pembentukan kemampuan dasar sesuai indikator pencapaian hasil belajar yang harus ditempuh (Trianto, 2011, p. 223). Berdasarkan pengertian Lembar Kerja Siswa (LKS), maka terdapat fungsi dari LKS itu sendiri. Prastowo (2013, p. 205) merumuskan fungsi LKS sebagai 1) Sebagai bahan ajar yang bisa meminimalkan peran pendidik, namun lebih mengaktifkan peserta didik; 2) Sebagai bahan ajar yang mempermudah peserta didik untuk memahami materi yang diberikan; 3) Sebagai bahan ajar yang ringkas dan kaya akan tugas untuk berlatih; dan 4) Memudahkan pelaks anaan pengajaran kepada peserta didik.

Penggunaan LKS dalam pelaksanaan pembelajaran matematika dapat memudahkan pelaksanaan pengajaran pendidik ke perserta didik. Penggunaan LKS dapat meminimkan peran pendidik sehingga siswa dapat lebih aktif untuk mencari atau mengolah materi yang diberikan. Meskipun demikian, guru diharapkan dapat membimbing dalam proses pembelajaram agar siswa lebih semangat dan tedorong untuk memahami materi dan mengerjakan soal yang ada di LKS. 


\section{Kriteria Lembar Kerja Siswa}

Kriteria Kualitas Lembar Kerja Siswa memberi pengaruh yang cukup besar dalam proses belajar mengajar, sehingga penyusunan LKS harus memenuhi berbagai persyaratan yaitu syarat didaktik, syarat konstruksi, dan syarat teknik. Sedangkan, pada proses pembuataan mengikuti langkahlangkah adalah sebagai berikut 1) Melakukan analisis kurikulum, ini bertujuan untuk menentukan materi mana saja yang memerlukan bahan ajar LKS. Caranya yaitu dengan melihat materi pokok, pengalaman belajar, serta materi yang akan diajarkan. 2) Menyusun peta kebutuhan LKS, tujuannya untuk mengetahui jumlah LKS yang harus dibuat serta mengetahui urutan-urutan materi dalam LKS. 3) Menentukan judul-judul LKS, dengan melihat kompetensi dasar, materi pokok, atau pengalaman belajar yang terdapat dalam kurikulum. Dan 4) Penulisan LKS, dengan langkah-langkahnya yaitu merumuskan kompetensi dasar, menentukan alat penilaian, menyusun materi dan memperhatikan struktur LKS (Prastowo, 2013).

\section{Model Pembelajaran kooperatif Tipe Kreatif-produktif}

Tipe kreatif-produktif adalah suatu penyajian materi ajar dengan mendorong siswa untuk mengembangkan ide kreatif yang produktif (Istarani \& Ridwan, 2014. p.109). Kreativitas dan prokdutivitas merupakan hal yang saling berkaitan dan dalam proses pembelajaran hal tersebut harus ditumbuhkan secara bersamaan (Wena, 2013, p. 138). Untuk menumbuhkan kreatifproduktif maka diperlukan kemampuan berfikir yang dapat menantang siswa untuk menghasilkan sesuatu dari pemahamannya terhadap masalah atau topik yang dikaji. Selanjutnya, untuk meningkatkan kreativitas siswa dapat dilakukan dengan 1) Mendorong siswa untuk kreatif (tell student to be creatif), Mengajari siswa beberapa metode untuk menjadi kreatif (teach student some creativity methods), Menerima ide-ide kreatif yang dihasikan siswa (accept the result of creatif exercise).

Menurut made wena, dalam pelaksanaan pembelajaran kreatif-produktif harus dilakukan dengan tahap-tahap tertentu. Terdapat lima tahap pembelajaran kreatif produktif yaitu: (a) orientasi, (b) eksplorasi, (c) interpretasi, (d) re-kreasi, (e) evalusi (Wena, 2013, p. 40).

penerapan model pembelajaran kreatif-produktif dikelas terhadap kegiatan guru dan siswa secara operasional selama pembelajaran dapat dijabarkan pada tabel 1.

Tabel 1. Penerpan Proses Pembelajaran Dikelas

\begin{tabular}{|c|c|c|c|}
\hline No & Tahap & Kegiatan Guru & Kegiatan Siswa \\
\hline 1 & Oientasi & $\begin{array}{l}\text { Mengkomunikasikan tujuan, materi, } \\
\text { waktu, langkah-langkah pembelajaran, } \\
\text { hasil yang diharapkan dan penilaian }\end{array}$ & $\begin{array}{l}\text { Menanggapi/mendiskusikan langkah-langkah } \\
\text { pembelajran, hasil yang diharapkan dan } \\
\text { penilaian. }\end{array}$ \\
\hline 2 & Ekplorasi & $\begin{array}{l}\text { Fasilitator, motivator, mengarahkan } \\
\text { dan membei bimbingan belajar. }\end{array}$ & $\begin{array}{l}\text { Membaca, melakukan observasi, wawancara, } \\
\text { melakukan percobaan, browsing, lewat } \\
\text { internet, dan sebagainya. }\end{array}$ \\
\hline 3 & Interpretasi & $\begin{array}{l}\text { Membimbing, fasilitator, } \\
\text { mengarahkan }\end{array}$ & $\begin{array}{l}\text { Analisis, diskusi, tanya jawab, atau berupa } \\
\text { percobaan kembali }\end{array}$ \\
\hline 4 & Re-Kreasi & $\begin{array}{l}\text { Membimbing, mengarahkan, memberi } \\
\text { dorongan, menumbuhkan daya cipta }\end{array}$ & $\begin{array}{l}\text { Mengambil keputusan, menghasilkan } \\
\text { sesuatu/produk yang baru }\end{array}$ \\
\hline 5 & Evaluasi & Melakukan evaluasi, memberi balikan & Mendiskusika hasil evaluasi \\
\hline
\end{tabular}

Sumber: diadaptasi Made Wena (2011:143)

\section{LKS dengan Model Kreatif-Produktif}

LKS Kreatif-Produktif bertujuan membantu siswa menemukan konsep, membantu siswa menerapkan dan mengintegrasikan berbagai konsep tersebut secara kreatif dan memperkuat pendalaman dan penerapan materi pembelajaran. LKS Kreatif-Produktif jika dapat berjalan dan diikuti dengan baik oleh siswa maka akan menghasilkan proses pembelajaran yang bermakna untuk meningkatkan kualitas proses dan hasil belajar, siswa berinteraksi langsung dengan sumber 
belajar secara langsung, siswa mengkonstruksi sendiri pengetahuannya, dan siswa dituntut harus mampu bekerja sama dan menghargai orang lain dalam kelompoknya.

Tahap awal kegiatan LKS Kreatif-Produktif ini adalah orientasi yaitu siswa bersama gurunya membahas tujuan, materi, waktu, langkah, dan hasil akhir yang diharapkan kepada siswa. Adapun kegiatan selanjutnya pada LKS ini siswa melakukan eksplorasi yang dapat dilakukan dengan membaca, melakukan percobaan, browsing internet dan sebagainya. Pada tahap ini siswa dirangsang untuk meningkatkan rasa ingin tahu. Kemudian, Tahap interpretasi yakni siswa menganalisis masalah/konsep/topik yang ada pada LKS secara berkelompok. Hal ini diharapkan siswa mampu bekerja sama dan menghargai orang lain dalam proses pembelajaran. Akhirnya tahap re-kreasi yakni siswa harus mengambil kesimpulan/menghasilkan sesuatu yang mencerminkan pemahamannya terhadap konsep/masalah yang telah mereka dapatkan. Selanjutnya di akhir pembelajaran akan diadakan evaluasi.

\section{METODE}

Jenis penelitian yang digunakan dalam penelitian ini adalah penelitian dan pengembangan (Research and Development). Research and Development adalah suatu penelitian yang digunakan untuk menghasilkan poduk tertentu, dan menguji keefektifan produk tersebut (Sugiyono, 2014). Penelitian dan pengembangan atau Research and Development (R \& D) suatu proses atau langkahlangkah untuk mengembangkan suatu produk baru atau menyempurnakan produk yang telah ada, yang dapat dipertanggung jawabkan (Sukmadinata, 2011). Produk yang dihasilkan dalam penelitian ini adalah LKS matematika model Kreatif-Produktif yang valid dan praktis dalam memfasilitasi kemampuan pemahaman konsep matematis siswa SMP/MTS kelas VIII semester 2 pada materi kubus dan balok. Model pengembangan yang digunakan adalah model ADDIE, yang terdiri dari lima tahap yaitu analysis, design, development, implementation, evaluation. Subjek uji coba kelompok kecil adalah kelas VIII.4 yang dipilih sebanyak 6 siswa, sedangkan subjek uji coba kelompok besar adalah kelas VIII.1 yang berjumlah 40 siswa. Objek penelitian LKS dengan model kreatif-produktif dan kemampuan pemahaman konsep matematis siswa di kelas VIII.1 SMP Negeri 21 Pekanbaru. Jenis data pada penelitian ini ialah data kualitatif dan data kuantitatif. Data kualitatif didapat dari hasil validasi oleh validator serta dari angket praktikalitas siswa. Data kuantitatif didapat dari hasil tes kemampuan pemahaman konsep siswa.

\section{HASIL}

Pada penelitian ini menghasilkan LKS dengan model Kreatif-Produktif, yang dikembangkan dengan tahap-tahap sebagai berikut:

\section{Tahap Analysis}

Pada tahap analysis terdapat dua analisis yang harus dilakukan yaitu analisis kinerja dan analisis kebutuhan. Analisis kinerja dilakukan dengan merinci isi materi ajar dalam bentuk garis besar yaitu mengacu pada KTSP 2006 materi kubus dan balok kelas VIII SMP. Analisis kebutuhan dilakukan dengan menentukan masalah dan solusi yaitu perlunya pengembangan LKS yang menarik minat siswa sehingga dapat meningkatkan prestasi belajarnya.

\section{Tahap Design}

Tahap design merupakan tahapan untuk merancang LKS matematika model Kreatif-Produktif serta komponen-komponen yang berkaitan dengan LKS tersebut. Bagian yang dirancang pada LKS adalah sebagai berikut: 
Cover

Cover merupakan salah satu unsur penting terhadap daya tarik siswa untuk membaca. Adapun gambar tampilan cover dari lembar kerja siswa model Kreatif Produktif seperti pada Gambar 1.

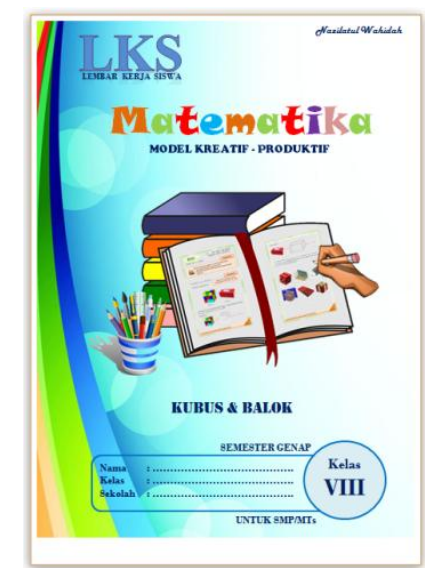

Gambar 1. Desain cover

\section{Kata pengantar dan daftar isi}

Kata pengantar berisi pengantar tentang LKS yang akan digunakan pada proses pembelajaran. Sedangkan daftar isi memudahkan untuk mencari halaman LKS.

\section{Bagian pendabuluan}

Pada bagian pendahuluan berisi tentang deskripsi singkat model pembelajaran kreatif-Produktif, petunjuk penggunaan LKS, standar kompetensi, kompetensi dasar, indikator dan tujuan pembelajaran.

Peta konsep

Peta konsep sangat penting baik bagi siswa maupun guru karena peta konsep menjadikan pembelajaran lebih terarah.

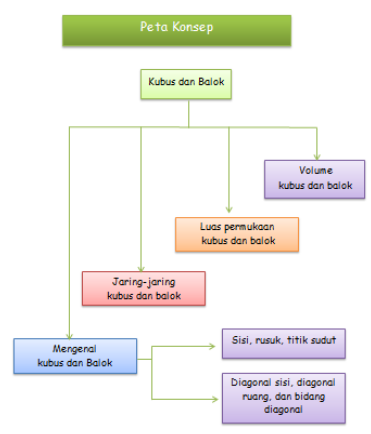

Gambar 2. Desain Peta Konsep

\section{Kegiatan belajar}

Produk pengembangan LKS dengan model Kreatif-Produktif ini terdiri dari empat kegiatan belajar yaitu: 1) Unsur-unsur kubus dan balok, 2) Jaring-jaring kubus dan balok, dan 3) Luas permukaan kubus dan balok, dan 4) Volume kubus dan balok 


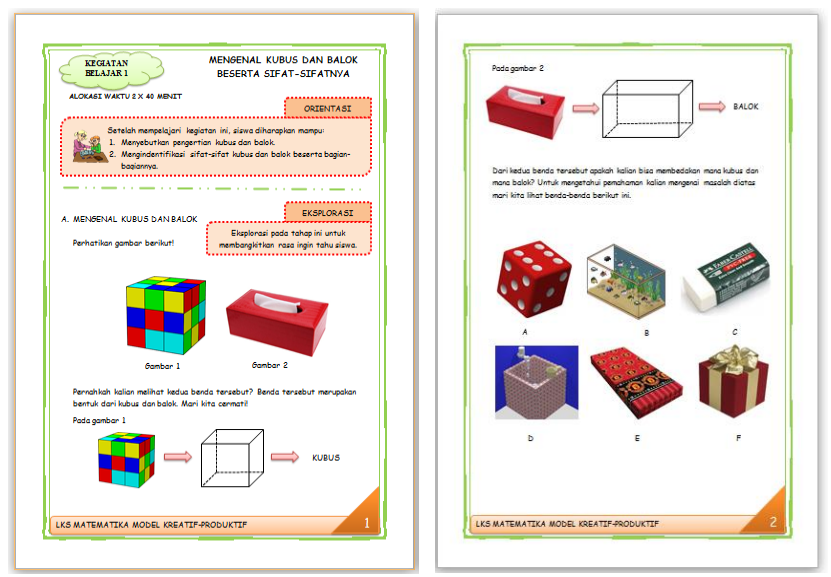

Gambar 3. Desain Kegiatan Belajar

\section{Tahap Development}

Setelah selesai pembuatan desain LKS, kemudian LKS yang dikembangkan divalidasi oleh validator ahli materi dan ahli teknologi pendidikan dengan menggunakan angket.

Hasil Validasi LKS oleh Abli Teknologi Pendidikan

Tabel 2. Hasil Validasi Ahli Teknologi Pendidikan terhadap LKS Matematika Model KreatifProduktif

\begin{tabular}{llll}
\hline No. & Kriteria LKS & Nilai Validasi & Kriteria \\
\hline 1 & Penggunaan huruf dan tulisan & $83,3 \%$ & Sangat Valid \\
2 & Desain LKS & $85 \%$ & Sangat valid \\
3 & Penggunaan gambar & $78,3 \%$ & Valid \\
4 & LKS berpenampilan menarik & $75 \%$ & Valid \\
\multicolumn{2}{l}{ Rata-rata } & $81 \%$ & Sangat valid \\
\hline
\end{tabular}

Berdasarkan tabel di atas, jelas terlihat bahwa persentase keseluruhan dari penilaian oleh ketiga ahli teknologi pendidikan adalah sangat valid, karena berada pada persentase keidealan $81 \%$ $\leq$ Nilai $\leq 100 \%$, sehingga LKS pembelajaran tidak memerlukan revisi. Namun, komentar dan saran dari ahli teknologi pendidikan dijadikan bahan perbaikan untuk menyempurnakan LKS pembelajaran.

Data Validasi oleh Abli Materi Pembelajaran

Tabel 3. Hasil Validasi Ahli Materi Pembelajaran terhadap LKS Matematika Model KreatifProduktif

\begin{tabular}{|c|c|c|c|c|c|}
\hline No & Variabel Validitas & Indikator & Nomor Pernyataan & $\begin{array}{l}\text { Nilai } \\
\text { Validitas }\end{array}$ & Kriteria \\
\hline \multirow{3}{*}{1} & \multirow{3}{*}{ Syarat Didaktif } & $\mathrm{A}$ & $1,2,3,4$ & $83,3 \%$ & Sangat Valid \\
\hline & & $\mathrm{B}$ & $5,6,7,8$ & $85 \%$ & Sangat Valid \\
\hline & & C & $9,10,11,12$ & $86,7 \%$ & Sangat Valid \\
\hline \multirow{5}{*}{2} & \multirow{5}{*}{ Syarat Konstruktif } & $\mathrm{A}$ & $13,14,15,16$ & $83,3 \%$ & Sangat Valid \\
\hline & & B & $17,18,19,20$ & $88,3 \%$ & Sangat Valid \\
\hline & & C & $21,22,23,24$ & $81,7 \%$ & Sangat Valid \\
\hline & & $\mathrm{D}$ & $25,26,27,28$ & $88,3 \%$ & Sangat Valid \\
\hline & & $\mathrm{E}$ & $29,30,31,32$ & $81,7 \%$ & Sangat Valid \\
\hline 3 & $\begin{array}{l}\text { Model Kreatif- } \\
\text { Produktif }\end{array}$ & & $33,34,35,26$ & $83,3 \%$ & Sangat Valid \\
\hline \multicolumn{3}{|c|}{ Rata-rata } & & $84,6 \%$ & Sangat Valid \\
\hline
\end{tabular}


Dari tabel di atas, diketahui bahwa persentase keseluruhan aspek LKS dari penilaian kedua ahli materi pembelajaran adalah sangat valid karena berada pada persentase keidealan $81 \% \leq$ Nilai $\leq 100 \%$.

Hasil Validasi Keseluruban (Abli Teknologi Pendidikan dan Abli Materi Pembelajaran)

Tabel 4. Perhitungan data hasil uji validitas Secara keseluruhan

\begin{tabular}{lll}
\hline No. & Variabel Validitas LKS & Persentase Keidealan \\
\hline 1 & Ahli Teknologi Pendidikan & $81 \%$ \\
2 & Ahli Materi Pembelajaran & $84,6 \%$ \\
Rata-rata & $82,8 \%$ \\
\hline
\end{tabular}

Berdasarkan tabel 4, diketahui bahwa persentase keseluruhan dari penilaian ahli teknologi pendidikan dan ahli materi pembelajaran adalah sangat valid karena berada pada persentase keidealan $81 \% \leq$ Nilai $\leq 100 \%$, sehingga LKS pembelajaran sudah layak untuk digunakan.

\section{Tahap Implementation}

Pada tahap implementasi ini, LKS diujicobakan kepada siswa SMP Negeri 21 Pekanbaru . Uji coba yang dilakukan adalah uji coba kelompok kecil yang dilakukan kepada 6 siswa yang diambil dari kelas VIII.4 SMP Negeri 21 Pekanbaru dan uji coba lapangan dilakukan di kelas VIII.1 SMP Negeri 21 Pekanbaru yang berjumlah 40 siswaPada tahap ini diperoleh data kepraktisan dan keberhasilan penggunaan LKS untuk memfasilitasi kemampuan pemahaman konsep matematis melalui angket dan tes.

Uji coba kelompok kecil

Tabel 4. Hasil Uji Praktikalitas Kelompok Kecil terhadap LKS Matematika Model Kreatif-Produktif

\begin{tabular}{llll}
\hline No & Variabel Praktikalitas & Nilai Praktikalitas & Kriteria \\
\hline 1. & Minat Siswa dan Tampilan LKS & $90,5 \%$ & Sangat Praktis \\
2. & Penggunaan LKS & $90,4 \%$ & Sangat Praktis \\
3. & Pemahaman Konsep dan Materi & $88,75 \%$ & Sangat Praktis \\
4. & Waktu & $90,8 \%$ & Sangat Praktis \\
5. & Evaluasi & $89,2 \%$ & Sangat Praktis \\
Rata-rata & $89,9 \%$ & Sangat Praktis \\
\hline
\end{tabular}

Berdasarkan tabel di atas, perhitungan keseluruhan data hasil uji praktikalitas kelompok kecil adalah 89,9\% sehingga dikategorikan sangat praktis karena berada pada persentase keidealan $81 \% \leq$ Nilai $\leq 100 \%$. Dari hasil tersebut maka LKS tidak memerlukan revisi lagi. Namun komentar dan saran dari siswa tetap dijadikan perbaikan untuk menyempurnakan LKS ini.

\section{Uji Coba Lapangan}

Berdasarkan tabel 5, perhitungan keseluruhan data hasil uji praktikalitas kelompok besar adalah $89,7 \%$ sehingga dikategorikan sangat praktis karena berada pada persentase keidealan $81 \%$ $\leq$ Nilai $\leq 100 \%$. Dari hasil ini maka LKS tidak memerlukan revisi lagi. Namun komentar dan saran tetap dijadikan untuk menyempurnakan LKS ini. 
Tabel 5. Hasil Uji Praktikalitas Kelompok Besar Terhadap LKS Matematika Model KreatifProduktif

\begin{tabular}{llll}
\hline No & Variabel Praktikalitas & Nilai Praktikalitas & Kriteria \\
\hline 1. & Minat Siswa dan Tampilan LKS & $90,8 \%$ & Sangat Praktis \\
2. & Penggunaan LKS & $88,4 \%$ & Sangat Praktis \\
3. & Pemahaman Konsep dan Materi & $89,2 \%$ & Sangat Praktis \\
4. & Waktu & $87,6 \%$ & Sangat Praktis \\
5. & Evaluasi & $92,6 \%$ & Sangat Praktis \\
Rata-rata & $89,7 \%$ & Sangat Praktis \\
\hline
\end{tabular}

Pada uji praktikalitas kelompok besar, siswa diberikan posttest pada akhir pembelajaran guna untuk mengetahui sejauh mana pemahaman konsep matematis siswa. Hasil posttest berdasarkan indikator pemahaman konsep dapat dijelaskan sebagai berikut.

Tabel 6. Hasil Posttest permahaman Konsep Matematis

\begin{tabular}{llll}
\hline \multirow{2}{*}{ No. } & $\begin{array}{l}\text { Indikator Kemampuan } \\
\text { Pemahaman Konsep Matematis }\end{array}$ & $\begin{array}{l}\text { Persentase } \\
\text { Keidealan }\end{array}$ & Predikat \\
\hline 1. & Menyatakan ulang sebuah konsep & $100 \%$ & Tinggi \\
2. & Mengklasifikasikan objek sesuai konsepnya & $78,1 \%$ & Sedang \\
3. & Memberikan contoh dan bukan contoh dari suatu konsep & $93,7 \%$ & Tinggi \\
4. & Menyajikan konsep dalam berbagai bentuk representasi & $84,4 \%$ & Tinggi \\
5. & Memberikan syarat perlu atau syarat cukup suatu konsep & $94,4 \%$ & Tinggi \\
6. & Menggunakan dan memanfaatkan serta memilih prosedur atau & $93,7 \%$ & Tinggi \\
7. $\quad$ Mengasi tertentu & $100 \%$ & Tinggi \\
Persentase Keidealan Keseluruhan & $92 \%$ & Tinggi \\
\hline
\end{tabular}

Berdasarkan tabel di atas, hasil posttest adalah 92\% sehingga diberi peringkat Tinggi karena berada pada tingkat penguasaan $80 \% \leq$ Nilai $\leq 100 \%$.

\section{Tahap Evaluation}

Pada tahap evaluasi ini dibahas mengenai perbaikan dari saran-saran ahli materi pembelajaran dan ahli teknologi pendidikan pada uji validitas dan siswa pada uji praktikalitas. Adapun saran dapat dilihat pada tabel 7.

Tabel 7. Saran Validator Terhadap LKS Matematika Model Kreatif-Produktif

\begin{tabular}{|c|c|c|c|}
\hline No. & Validator & Saran & Perbaikan \\
\hline 1. & $\begin{array}{l}\text { Validator ahli teknologi } \\
\text { pendidikan I. }\end{array}$ & $\begin{array}{l}\text { Design cover, konsistensi penomoran, konsistensi } \\
\text { spasi, dan konsistensi tulisan, peta konsep }\end{array}$ & Sudah diperbaiki \\
\hline 2. & $\begin{array}{l}\text { Validator ahli teknologi } \\
\text { pendidikan II. }\end{array}$ & $\begin{array}{l}\text { Pengetikan materi, nomor halaman, penggunaan } \\
\text { gambar di kanan keterangan }\end{array}$ & Sudah diperbaiki \\
\hline 3. & $\begin{array}{l}\text { Validatir ahli tekhnologi } \\
\text { pendidikan III }\end{array}$ & Penggunaan warna dan animasi pada LKS & Sudah diperbaiki \\
\hline 3. & $\begin{array}{l}\text { Validator ahli materi } \\
\text { pembelajaran I }\end{array}$ & $\begin{array}{l}\text { Daftar refensi, gambar kubus dan balok disesuaikan } \\
\text { dengan kaedah geometri, penggunaan kata, kolom } \\
\text { jawaban pada evaluasi }\end{array}$ & Sudah diperbaiki \\
\hline 4. & $\begin{array}{l}\text { Validator ahli materi } \\
\text { pembelajaran II }\end{array}$ & Kolom penilaian dan penggunaan kata & Sudah diperbaiki \\
\hline 5. & $\begin{array}{l}\text { Validator ahli materi } \\
\text { pembelajaran III }\end{array}$ & $\begin{array}{l}\text { Soal sesuaikan dengan tingkat SMP dan gambar } \\
\text { kubus dan balok sesuai kaedah geometri }\end{array}$ & Sudah diperbaiki \\
\hline
\end{tabular}


Perubahan yang terjadi pada tahap evaluasi ini dapat dilihat pada gambar 4.

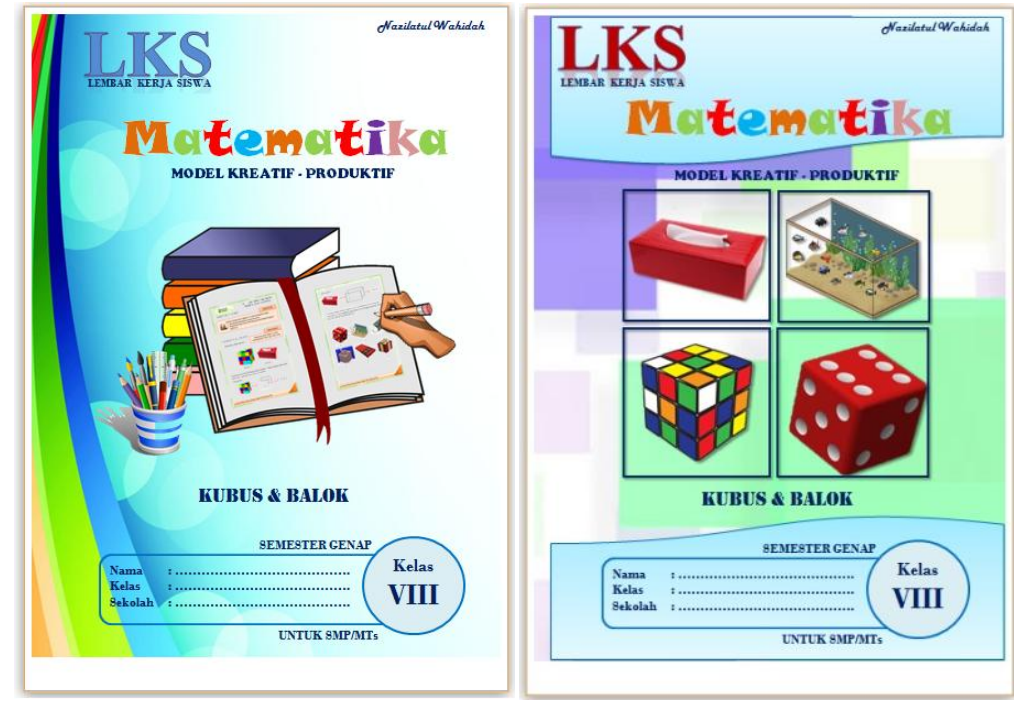

Gambar 4. Cover sebelum dan sesudah direvisi

LKS yang telah direvisi berdasarkan saran-saran dari para validator kemudian diujicobakan kepada kelompok kecil yang terdiri dari 6 siswa. Hal ini dilakukan untuk menguji apakah masih ditemukan kesalahan dan kekurangan pada LKS. Dari hasil uji praktikalitas kelompok kecil ini diperoleh kategori Sangat Praktis oleh siswa, namun saran-saran yang diberikan tetap dijadikan bahan perbaikan. Adapun saran tersebut adalah sebagai berikut:

Tabel 8. Saran Siswa Kelompok Kecil Terhadap LKS Matematika Model Kreatif-Produktif

\begin{tabular}{lll}
\hline No. & Saran & Keterangan \\
\hline 1. & $\begin{array}{l}\text { Jawaban dari soal lebih di bulatkan lagi angka- } \\
\text { angkanya }\end{array}$ & Sudah diperbaiki \\
2. & Tambahkan gambar yang lebih menarik & Sudah diperbaiki \\
\hline
\end{tabular}

Selanjutnya LKS diujicobakan kepada kelompok besar dari siswa kelas VIII.1 yang berjumlah 40 siswa. Ternyata LKS mendapat kategori Sangat Praktis. Dengan demikian LKS model Kreatif-Produktif telah valid dan praktis sehingga layak untuk digunakan sebagai bahan ajar.

\section{PEMBAHASAN}

Hasil analisis data validasi ahli teknologi pendidikan menunjukkan bahwa LKS model Kreatif Produktif yang dikembangkan berdasarkan syarat teknis mendapat kategori sangat valid dengan persentase keidealan $81 \%$. desain LKS model Kreatif-Produktif mendapat kategori sangat valid dengan persentase keidealan 85\%. penggunaan gambar pada LKS model Kreatif-Produktif mendapat kategori sangat valid dengan persentase keidealan 78,3\%. penampilan LKS model Kreatif-Produktif sudah sangat valid dengan persentase 75\%. Hasil penilaian oleh ahli teknologi pendidikan tersebut menunjukkan LKS model Kreatif-Produktif sudah sangat valid dan dapat digunakan dalam pembelajaran matematika.

Ahli materi pembelajaran menunjukkan bahwa LKS model Kreatif-Produktif yang dikembangkan mendapat kategori sangat valid dengan persentase keidealan 84,6\%. LKS matematika model Kreatif-Produktif mendapat kategori sangat valid dengan persentase $85 \%$. LKS matematika model Kreatif-Produktif mendapat kategori sangat valid dengan persentase 84,7\%. Berdasarkan model Kreatif-Produktif bahwa LKS matematika model Kreatif-Produktif mendapat kategori sangat valid dengan persentase $83,3 \%$. Penilaian oleh ahli materi pembelajaran tersebut 
menunjukkan LKS model Kreatif-Produktif sudah sangat valid dan dapat digunakan dalam pembelajaran matematika. Sedangkan hasil analisis data praktikalitas kelompok kecil menunjukkan bahwa LKS model Kreatif-Produktif yang dikembangkan mendapatkan kategori sangat praktis dengan persentase keidealan 89,9\%. Hasil analisis data praktikalitas kelompok besar menunjukkan bahwa LKS model Kreatif-Produktif yang dikembangkan mendapatkan kategori sangat praktis dengan persentase keidealan 89,7\%. Selain itu, hasil analisis data posttest kemampuan pemahaman konsep menunjukkan bahwa rata-rata persentase keidealan nilai siswa adalah $92 \%$ dengan predikat Tinggi. Penilaian ini menunjukkan bahwa LKS model Kreatif-Produktif telah dapat memfasilitasi kemampuan pemahaman konsep matematis siswa siswa.

Berdasarkan hasil analisis data dapat disimpulkan bahwa LKS berbasis masalah yang dikembangkan memiliki karakteristik valid dan praktis. Berdasarkan penelitian yang telah dilakukan, peneliti merekomendasikan hal-hal berikut: (1) Bagi guru dapat menggunakan LKS matematika model Kreatif-Produktif dalam proses pembelajaran materi kubus dan balok karena telah diujicobakan dan hasilnya valid, praktis serta dapat memfasilitasi kemampuan pemahaman konsep matematis. (2) LKS model Kreatif-Produktif dikembangkan lebih lanjut dan mendalam dengan melakukan eksperimen mengunakan kelas pembanding agar kualitas LKS ini lebih teruji keefektifannya. (3) Bagi peneliti selanjutnya hendaklah mengembangkan LKS model KreatifProduktif dengan materi yang berbeda dan pada materi yang lebih luas lagi.

\section{DAFTAR RUJUKAN}

Badan Standar Nasional Pendidikan. (2006). Model Peneilaian Kelas. Jakarta: Depdiknas Gulo, W. (2008). Strategi Belajar Mengajar. Jakarta: Grasindo

Hutagalung, R.(2017). Peningkatan Kemampuan Pemahaman Konsep Matematis Siswa melalui Pembelajaran Guided Discovery berbasis Budaya Toba Di SMP Negeri 1 Tukka. MES (Journal of Mathematics Education and Science), 2(2), 70-77

Isatarani \& Ridwan, M. (2014). 50 Tipe Pembelajaran Kooperatif. Medan: CV. Media Persada.

Menteri Pendidikan Nasional. (2006). Peraturan Menteri Pendidikan Nasional: Standar Isi untuk Satuan Pendidikan Dasar dan Menengah. (Nomor 22 tahun 2006). Jakarta: Kementerian Pendidikan Nasional

Prastowo, A. (2013). Panduan Kreatf Membuat Bahan Ajar Inovatif. Yogyakarta: DIVA Press

Risnawati. (2008). Strategi Pembelajaran Matematika. Pekanbaru: Suska Press

Rusia, I., Fahinu, \& Tiya, K. (2016). Pengaruh Pendekatan Saintifik Terhadap Kemampuan Pemahaman Matematis Siswa Kelas Viii Smpn 10 Kendari. Jurnal Penelitian Pendidikan Matematika, 4(2), 85 - 98

Saltifa, P., Irwan, \& Dewi, M.P. (2012). Penggunaan Lembar Kerja Siswa (LKS) dalam Memahami Konsep Matematika. Jurnal Pendidikan Matematika, 1(1), 73-76

Sugiono. 2014. Metode Penelitian Pendidikan. Bandung: Alfabeta

Suherman, E. (2001). Strategi Pembelajran Matematika Kontemporer. Bandung: JICA

Sukmadinata, N. S. (2011). Metode Penelitian Pendidikan. Bandung: PT Remaja Roskadarya. cet. 7

Sumarsih. (2016) Analisis Kesulitan Siswa SMP dalam Mempelajari Persamaan Garis Lurus dan Alternatif Pemecahannya. Prosiding Seminar Matematika dan Pendidikan Matematika, November 2016, 415-430

Trianto. (2011). Mendesain Model Pembelajaran Inovatif-Progresif Konsep Landasan dan Implementasinya Pada Kurikulum tingkat Satuan Pendidikan (KTSP). Jakarta: Kencana.

Tuzahrah, F., Rasiman, Z. \& Ijuddin, R. (2016). Analisis Kesulitan Belajar Siswa Dalam Menyelesaikan Soal Bilangan Berpangkat Di Kelas X SMA. Jurnal Pendidikan dan Pengajaran, 5(10), 1-8 
Uno, H. B. (2011). Model Pembelajaran. Jakarta: Bumi Aksara

Utari, V., Fauzan, A., \& Rosha, M. (2012). Peningkatan Kemampuan Pemahaman Konsep Melalui Pendekatan PMR dalam Pokok Bahasan Prisma dan Limas. Jurnal Pendidikan Matematika, 1(1), 33-38.

Wena, M. (2011). strategi pembelajaran inovatif kontempotrer.Jakarta: Bumi Aksara

Wihaya, A. (2012). Pendidikan Matematika Realiastik. Yogyakarta: Graha Ilmu

Zein, M. dan Darto. (2012). Evaluasi Pembelajaran Matematika. Pekanbaru: Daulat Riau 